\title{
Paraneoplastiske nevrologiske syndromer
}

\author{
Sammendrag \\ Bakgrunn. Paraneoplastiske nevrolo- \\ giske syndromer er en heterogen syk- \\ domsgruppe hvor pasientene har alvor- \\ lige nevrologiske utfall. De siste 20 \\ årene har det pågått intens forskning \\ på dette feltet, og det har ført til karak- \\ terisering av stadig nye subgrupper og \\ immunresponser.
}

\begin{abstract}
Materiale og metode. Artikkelen er bygd på ikke-systematisk søk i PubMed samt på forfatternes egen erfaring med klinisk håndtering, antistoffanalyse og forskningskompetanse innenfor området.
\end{abstract}

Resultater og fortolkning. Paraneoplastiske nevrologiske syndromer rammer under $1 \%$ av alle kreftpasienter. Bakgrunnen for syndromene er en sannsynlig autoimmun reaksjon med både humoral og cellulær immunaktivering mot en kreftsvulst utenfor nervesystemet og mot nevroner. Onkonevrale antistoffer, på norsk oftest kalt nevronantistoffer, kan påvises hos en del av pasientene, og er meget spesifikke markører for paraneoplastisk nevrologisk sykdom. Påvisning og behandling av den tilgrunnliggende svulsten er vesentlig for prognosen, og immunmodulerende behandling blir ofte gitt i tillegg for å behandle de nevrologiske symptomene.

\author{
Anette Storstein \\ astt@helse-bergen.no \\ Christian A. Vedeler \\ Nevrologisk avdeling \\ Haukeland universitetssykehus \\ 5021 Bergen \\ og \\ Seksjon for nevrologi \\ Institutt for klinisk medisin \\ Universitetet i Bergen
}

Paraneoplastiske nevrologiske sykdommer (PNS) er en samlebetegnelse for en gruppe tilstander som rammer nervesystemet sekundært til kreftsykdom i et annet organ, og som sannsynligvis er mediert via autoimmune mekanismer. Samlet forekommer disse tilstandene hos under $1 \%$ av alle kreftpasienter, og er hyppigst ved svulster i lunger, thymus, bryst og indre genitalia (1).

Sammenhengen mellom visse former for nevrologisk sykdom og kreft har vært kjent i mange tiår, men først i slutten av 1980årene lyktes man å vise at mange pasienter med paraneoplastiske nevrologiske sykdommer har spesifikke autoantistoffer rettet mot nervevev, såkalte onkonevrale antistoffer eller nevronantistoffer. Disse antistoffene er rettet mot antigener som uttrykkes både av kreftcellene og av normale celler i sentralnervesystemet (onkonevrale antigener). Denne oppdagelsen ga mistanke om at paraneoplastiske nevrologiske sykdommer er autoimmune sykdommer, og senere forskning har bekreftet dette for flere typer av disse syndromene (2).

Syndromene kan ramme alle nivåer av nervesystemet og forårsaker ofte multifokale symptomer. Liknende nevrologiske symptomer kan oppstå av andre årsaker, og paraneoplastiske nevrologiske sykdommer er derfor en eksklusjonsdiagnose. Hos pasienter med kjent kreft er det spesielt viktig først å utelukke metastaser til nervesystemet eller nevrotoksiske effekter av kjemoterapi eller strålebehandling.

Selv om syndromene er heterogene, er det visse fellestrekk: De nevrologiske symptomene oppstår før kreftdiagnose hos 60-70\%; den tilgrunnliggende svulsten er ofte liten; symptomdebut er subakutt og forløpet progredierende hos de fleste pasientene, og symptomene kan være meget uttalte eller livstruende og kan gi alvorlige sekveler (3). Enkelte svulsttyper er hyppigere assosiert med paraneoplastiske nevrologiske sykdommer enn andre, men nesten alle svulster kan potensielt gi opphav til slike syndromer. Fordi kreft er en så vanlig sykdom, kan en tidsmes- sig sammenheng mellom nevrologiske symptomer og kreftdiagnose også være tilfeldig, men sykdomsutviklingen og det kliniske bildet vil være til stor hjelp i denne vurderingen.

Syndromer som er velkarakteriserte og som ofte har sammenheng med kreftsykdom kalles klassiske paraneoplastiske nevrologiske syndromer (tab 1). En rekke andre nevrologiske sykdommer kan være paraneoplastiske, men har også ofte annen etiologi (ikke-klassiske syndromer) (4). Emnet har tidligere vært behandlet $\mathrm{i}$ Tidsskriftet (5). I det følgende presenterer vi en oppdatert oversikt over de forskjellige kliniske tilstandene med hovedvekt på klassiske paraneoplastiske nevrologiske syndromer, diagnostikk og behandling, og nyere forskning i dette feltet.

\section{Materiale og metode}

Artikkelen er bygd på et ikke-systematisk PubMed-søk med hovedvekt på nyere litteratur. Forfatterne har bred egen erfaring med diagnose og klinisk håndtering av paraneoplastiske nevrologiske syndromer og har drevet aktiv forskning på feltet gjennom en rekke år.

\section{Syndromer \\ Paraneoplastisk encefalomyelitt}

Dette er en samlebetegnelse for det vanligste paraneoplastiske syndromet som rammer det sentrale nervesystemet. Syndromet er sterkt assosiert med Hu-antistoffer. Fordi Hu-antigenet uttrykkes i alle nevroner, kan pasientene få symptomer fra samtlige deler av nervesystemet. Den hyppigste kombinasjonen er fokal eller mer utbredt encefalitt $i$ kombinasjon med sensorisk nevronopati, og innslag av autonom nevropati (6). Et slikt sammensatt syndrom benevnes paraneoplastisk encefalomyelitt/sensorisk nevrono-

\section{Hovedbudskap}

- Paraneoplastiske nevrologiske syndromer er autoimmune, heterogene tilstander som rammer alle deler av nervesystemet

- Syndromene debuterer ofte subakutt og gir alvorlige nevrologiske symptomer og senfølger

- Nevronantistoffer er spesifikke mark $\varnothing$ rer, men fravær av antistoff utelukker ikke diagnosen 
pati. Syndromet er oftest assosiert med lungekreft. Prognosen er dårlig, og kun $20 \%$ er $i$ live etter tre år $(6,7)$.

\section{Paraneoplastisk limbisk encefalitt}

Den klassiske symptomtriaden ved limbisk encefalitt er personlighetsendring, epileptiske anfall og amnesi, som tidligere beskrevet i Tidsskriftet (8). Limbisk encefalitt er ofte et ledd i paraneoplastisk encefalomyelitt, med symptomer fra hypothalamus, hjernestamme og det perifere nervesystem, men kan også opptre isolert. Selv om de fleste pasientene har kreftsykdom (oftest småcellet lungekreft), er limbisk encefalitt også assosiert med mer godartede svulster som tymom (9). Nylig har limbisk encefalitt assosiert med teratom og antistoffer mot deler av N-methyl-D-aspartase (NMDA)-reseptoren blitt beskrevet (10), og en del pasienter har også antistoffer mot spenningsavhengige kaliumkanaler (VGKCantistoffer) (8). Limbisk encefalitt kan også forekomme av andre årsaker, for eksempel som en postinfeksiøs tilstand (8).

\section{Paraneoplastisk hjernestammeencefalitt}

Hjernestammeencefalitt kan opptre isolert, men oftere i sammenheng med paraneoplastisk encefalomyelitt, cerebellar degenerasjon eller limbisk encefalitt $(11,7)$. Dette er en meget alvorlig tilstand med progredierende nevrologiske symptomer, det kliniske bildet er avhengig av hvilket nivå i hjernestammen som er affisert. Hjernenerveutfall og/eller tetraparese er vanlig, og oftest rammes også bevissthet og respirasjon (11). Selv med adekvat behandling har hjernestammeencefalitt ofte dødelig utgang. Denne type paraneoplastisk sykdom er hyppigst assosiert med lunge-, bryst- eller testikkelkreft .

\section{Paraneoplastisk cerebellar degenerasjon}

Ved cerebellar degenerasjon utvikler pasientene progredierende symptomer fra cerebellum og hjernestamme, med kvalme, dysartri, ataksi, diplopi eller andre øyemotilitetsforstyrrelser. Tilstanden stabiliserer seg ofte etter to-tre måneder, men pasientene forblir pleietrengende (12). Dødeligheten er høy, særlig ved ledsagende symptomer fra andre deler av nervesystemet. Kreft i eggstokker og bryst er den vanligste årsaken, og symptomene skyldes en irreversibel skade av purkinjecellene i cerebellum (12).

\section{Paraneoplastisk opsoklonus-myoklonus}

Tilstanden karakteriseres av rykkvise og kaotiske øyebevegelser ledsaget av myoklonier i andre kroppsavsnitt. Dette er det eneste paraneoplastiske nevrologiske syndromer som også rammer barn og er da assosiert med nevroblastom. Paraneoplastisk opsoklonus-myoklonus skyldes affeksjon av hjernestammen, og har ubehandlet en dårlig prognose. Paraneoplastisk opsoklonus-myoklonus kan ses ved ulike krefttyper som lunge-, bryst- eller testikkelkreft. Ikkeparaneoplastisk opsoklonus-myoklonus kan
Tabell 1 Klassiske og ikke-klassiske paraneoplastiske nevrologiske syndromer. Klassiske syndromer er definert som velkarakteriserte tilstander som hyppig er assosiert med kreftsykdom Syndromer i parentes blir ikke diskutert i denne oversikten

\begin{tabular}{|c|c|c|}
\hline Lokalisasjon & Klassiske syndromer & $\begin{array}{l}\text { Andre syndromer } \\
\text { (ikke-klassiske) }\end{array}$ \\
\hline $\begin{array}{l}\text { Det sentrale nerve- } \\
\text { system }\end{array}$ & $\begin{array}{l}\text { Paraneoplastisk encefalomyelitt } \\
\text { Limbisk encefalitt } \\
\text { Cerebellar degenerasjon } \\
\text { Paraneoplastisk opsoklonus- } \\
\text { myoklonus }\end{array}$ & $\begin{array}{l}\text { Hjernestammeencefalitt } \\
\text { Ekstrapyramidale syndromer } \\
\text { Syndromer med visuelle sym- } \\
\text { ptomer } \\
\text { Autoimmunt stivhetssyndrom } \\
\text { Stiff person syndrome }\end{array}$ \\
\hline $\begin{array}{l}\text { Det perifere nerve- } \\
\text { system }\end{array}$ & $\begin{array}{l}\text { Subakutt sensorisk nevronopati } \\
\text { Kronisk gastrointestinal pseudoileus }\end{array}$ & $\begin{array}{l}\text { Sensorisk-motorisk nevropati } \\
\text { (Nevropati ved paraproteinemi) } \\
\text { (Nevropati ved vaskulitt) }\end{array}$ \\
\hline $\begin{array}{l}\text { Nevromuskulær over- } \\
\text { gang og muskel }\end{array}$ & $\begin{array}{l}\text { Lambert-Eatons myastenisk } \\
\text { syndrom } \\
\text { Dermatomyositt }\end{array}$ & $\begin{array}{l}\text { Myasthenia gravis } \\
\text { (Ervervet nevromyotoni) }\end{array}$ \\
\hline
\end{tabular}

skyldes viral infeksjon, medikamenter eller være idiopatisk (13).

\section{Paraneoplastisk sensorisk nevronopati}

Denne tilstanden affiserer primært forhornsnevronene (sensoriske ganglier), og forårsaker smertefull og ofte asymmetrisk nevronopati. Symptomene kan starte i en ekstremitet, men i løpet av uker til måneder affisere andre ekstremiteter, ansikt eller truncus. Pasientene har vanligvis initialt sensorisk ataksi, men etter hvert vil alle sansekvaliteter bli affisert, og det kan også tilkomme symptomer fra motoriske og autonome nerver (14). Paraneoplastisk sensorisk nevronopati har som regel en subakutt utvikling og er debutsymptomet hos mer enn $50 \%$ av pasientene med paraneoplastisk encefalomye-

litt. Nevronopatien er oftest assosiert med småcellet lungekreft $(6,14)$.

\section{Paraneoplastisk autonom nevropati}

Det vanligste symptomet er nedsatt tarmmotilitet eller kronisk pseudoileus, med ileussymptomer som kvalme, obstipasjon og abdominalsmerter (15). Andre autonome symptomer som ortostatisk hypotensjon, munntørrhet og impotens er også vanlig. Tilstanden debuterer ofte subakutt og progredierer raskt. De autonome symptomene ved paraneoplastiske nevrologiske syndromer skiller seg ikke fra andre typer alvorlig autonom svikt, men pasientene har oftest nevrologiske tilleggssymptomer, særlig fra det sentrale nervesystem eller sensoriske nerver (16). Hos slike pasienter er bakhornsnevro-

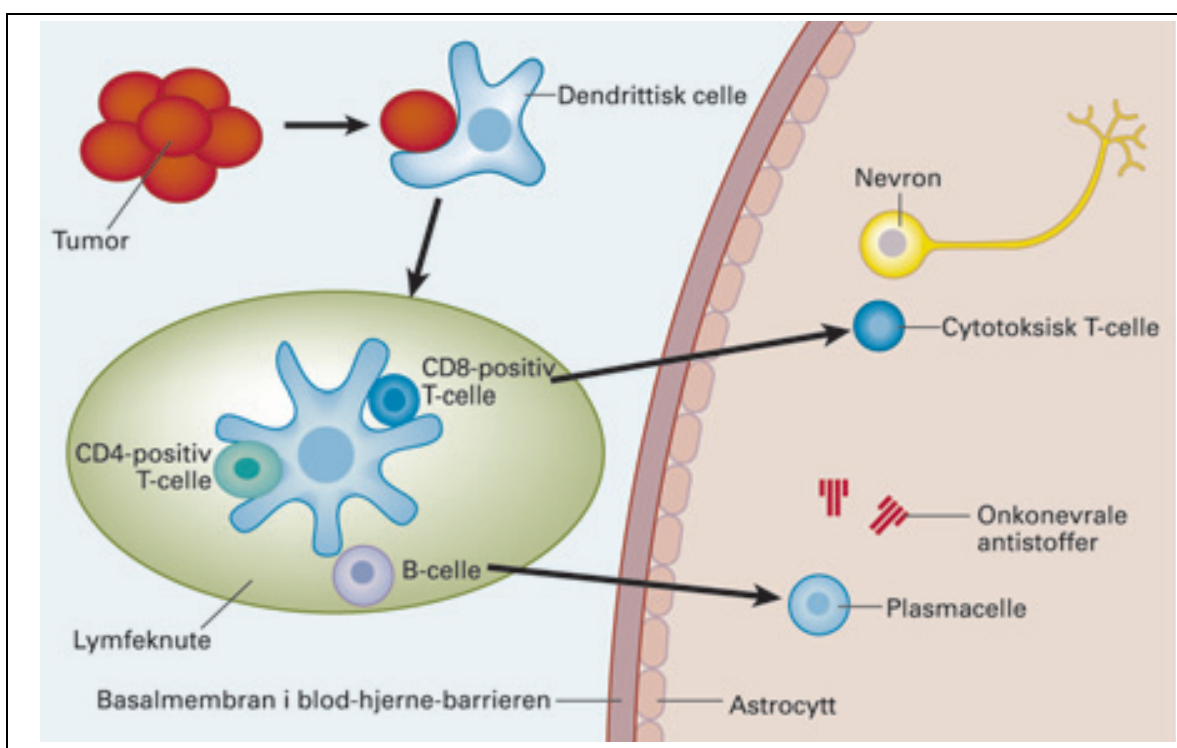

Figur 1 Patogenese ved paraneoplastiske nevrologiske syndromer. Ved slike syndromer presenterer dendrittiske celler og makrofager onkonevrale antigener til CD4-positive og CD8-positive T-celler i regionale lymfeknuter. CD8-positive T-celler kan så virke cytotoksisk mot kreftceller og nerveceller. CD4-positive T-celler aktiverer B-celler til plasmaceller som produserer antistoffer mot onkonevrale antigener. En slik immunreaksjon kan dempe kreftsvulstens vekst, men kan også medføre skade av friske nevroner og utløse nevrologisk sykdom. For eksempel vil aktiverte CD8positive $T$-celler mot $Y_{0}$-antigen og Yo-antistoff kunne føre til tap av purkinjeceller, som er karakteristisk for paraneoplastisk cerebellar degenerasjon 

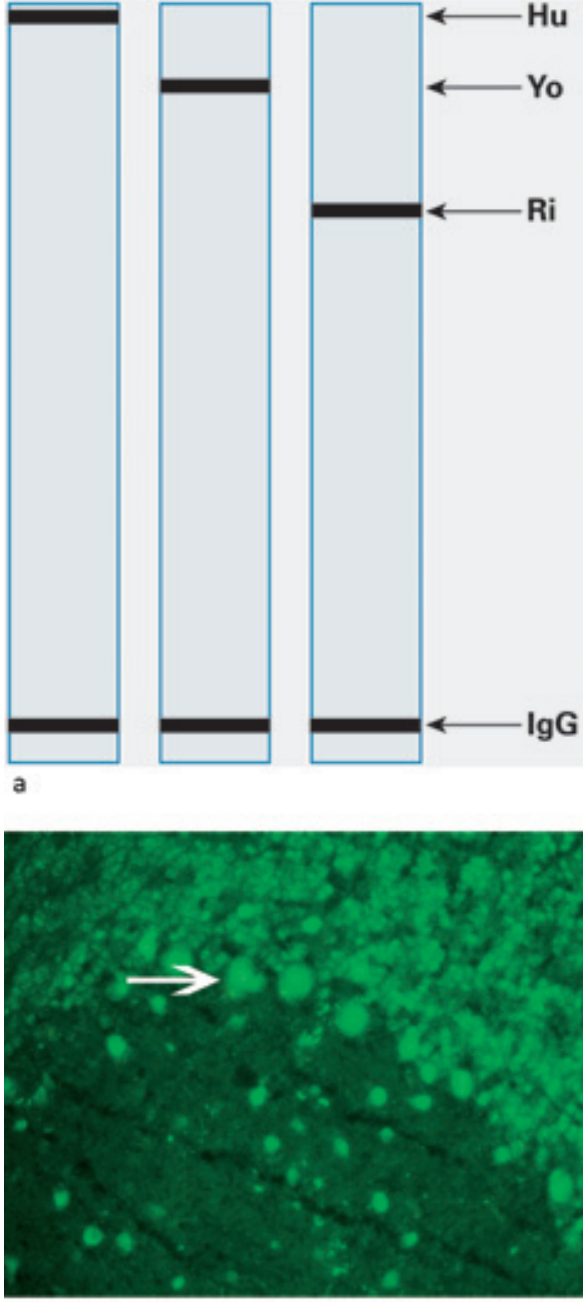

b

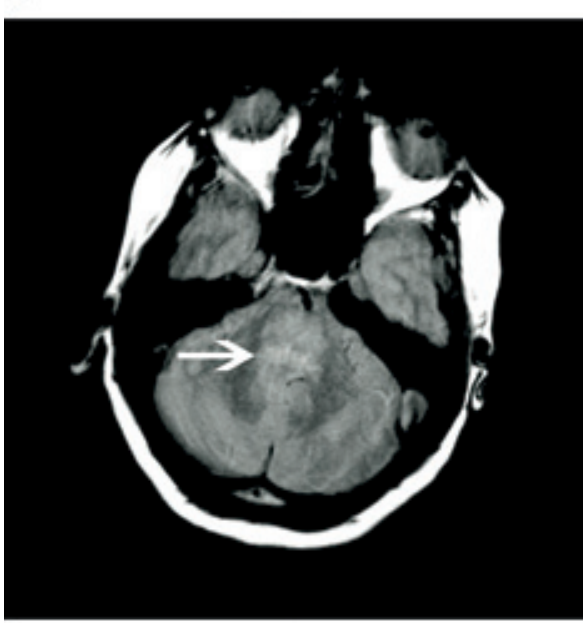

c

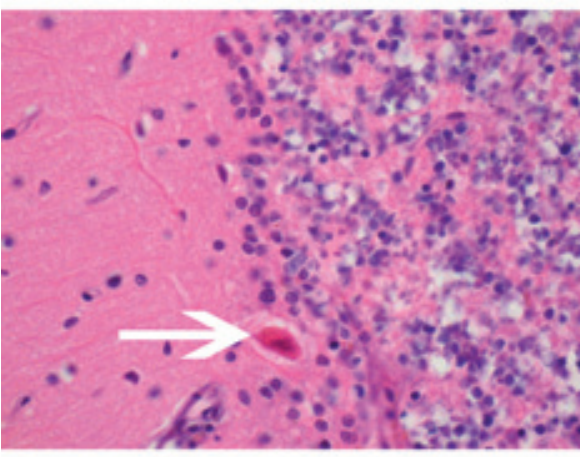

d ner og nevroner i autonome ganglier i tarmen affisert. Paraneoplastisk autonom nevropati er som regel assosiert med småcellet lungekreft (16)

\section{Paraneoplastisk}

sensorisk-motorisk nevropati

Paraneoplastisk sensorisk-motorisk nevropati kan starte subakutt og likne GuillainBarrés syndrom, eller ha et mer kronisk forløp. Nevropatien kan også arte seg som asymmetrisk polynevropati eller pleksopati. Nevropatien har oftest et progredierende forløp og oppstår innen et par år før eller etter kreftdiagnosen. Det er oftest tegn på inflammasjon i spinalvæsken, og noen pasienter har også nevronantistoffer (17). Ca. $8 \%$ av alle pasienter som etter utredning får diagnosen idiopatisk nevropati, viser seg retrospektivt å ha en paraneoplastisk nevropati (18). Paraneoplastiske nevropatier er som regel primært aksonale og er assosiert med ulike kreftformer, men oftest med småcellet lungekreft. Kronisk primært demyeliniserende sensorisk-motorisk polynevropati kan også opptre ved ulike former for paraproteinemi, f.eks. Waldenstrøms makroglobulinemi (19).

\section{Lambert-Eatons myastenisk syndrom og myasthenia gravis}

Lambert-Eatons myastenisk syndrom rammer den presynaptiske delen av den nevromuskulære overgangen, og pasientene har spenningsavhengige antistoffer mot kalsiumkanaler (VGCC-antistoffer). Pasientene utvikler proksimal muskelsvakhet og har ofte autonome symptomer som munntørrhet og impotens, mens diplopi, bulbære symptomer og generell trettbarhet er mindre uttalt ved LambertEatons myastenisk syndrom enn ved myasthenia gravis. Dette syndromet er paraneoplastisk i ca. $50 \%$ av tilfellene (oftest småcellet lungekreft), og ca. $10 \%$ av pasientene med myasthenia gravis har tymom $(20,21)$

\section{Andre paraneoplastiske} nevrologiske syndromer

Autoimmunt stivhetssyndrom med uttalt muskulær stivhet i truncus og ekstremiteter

Figur 2 Diagnostikk ved paraneoplastiske nevrologiske syndromer. al Serum fra pasienter med nevronantistoffer viser bånd som representerer ulike antistoffer (illustrert ved tegning). Den benyt tede teknikken er et kommersielt immunblot som brukes til å påvise de vanligste nevronantistoffene. b) Serum fra en pasient med Hu-antistoffer reagerer med kjernene i purkinjeceller i snitt fra rottehjerne i typisk bindingsmønster lpil på kjernefarging i purkinjecellene). c) MR av hjernen til en pasient med hjernestammeencefalitt viser hyperintensitet i hjernestammen (pil). d) Autopsi av lillehjernen til en pasient med paraneoplastisk cerebellar degenerasjon og Yo-antistoffer viser nærmest fullstendig tap av purkinjecellene etter to års sykdomsforløp; kun en gjenværende purkinjecelle (pil) med pyknotisk utseende ses kan være paraneoplastisk og er da assosiert med amfifysin-antistoffer og lunge- eller brystkreft (22). Syndromet er imidlertid oftest ikke paraneoplastisk, og mange pasienter har antistoffer mot glutamatdekarboksylase (GAD65), med eller uten diabetes mellitus (23). Ensidig eller dobbeltsidig tap av visus kan forekomme som paraneoplastiske nevrologiske syndromer hos pasienter med malignt melanom eller småcellet lungekreft, og man kan da påvise antistoffer mot det retinale proteinet recoverin (24). Ekstrapyramidale tilstander, spesielt chorea, kan av og til være paraneoplastisk og assosiert med CRMP5-antistoffer (25). Videre er dermatomyositt assosiert med ulike kreftformer, men ved denne tilstanden er det ingen kjente paraneoplastiske antistoffer (26).

\section{Patogenese}

Uttrykking av et onkonevralt antigen i pasientens svulst og presentasjon av dette antigenet for immunapparatet er nødvendige faktorer i patogenesen ved paraneoplastiske nevrologiske sykdommer. Slike onkonevrale antigener uttrykkes hyppig i mange svulsttyper, spesielt i småcellet lungekreft, medulloblastom, tymom og svulster i bryst og eggstokker $(3,27)$. Også godartede svulster kan uttrykke onkonevrale antigener som kan gi opphav til paraneoplastiske nevrologiske syndromer, eksempelvis kan pasienter med teratomer utvikle limbisk encefalitt. De onkonevrale antigenene uttrykkes normalt bare i immunprivilegerte organer som nervesystemet og oppfattes som kroppsfremmede antigener når de uttrykkes i en svulst. Antigenpresentasjonen resulterer derfor i aktivering og differensiering av CD4-positive og CD8positive T-celler, og differensiering av Bceller til plasmaceller som starter produksjon av det relevante nevronantistoffet (fig 1) $(2,27)$.

Nevronantistoffer som er rettet mot overflateantigener eller mot deler av ionekanaler, kan være patogene, for eksempel VGCCantistoffer ved Lambert-Eatons myastenisk syndrom (3). Dette er også vist i dyremodeller. Disse tilstandene rammer oftest det perifere nervesystemet. Imidlertid kan VGCCantistoffer også være assosiert med paraneoplastisk cerebellar degenerasjon. Nevronantistoffene som er assosiert med paraneoplastiske nevrologiske sykdommer i sentralnervesystemet, er derimot oftest rettet mot intracellulære antigener, og man har ikke med sikkerhet kunnet påvise at disse antistoffene har patogen betydning. Ved autopsi av pasienter med paraneoplastiske nevrologiske syndromer påvises det inflammatoriske infiltrater med T-celler og av og til B-celler i de områdene av nervesystemet hvor det relevante antigenet uttrykkes. T-celleaktivering kan derfor tenkes å være en viktig patogen faktor ved slike syndromer i sentralnervesystemet, men dette er ikke bekreftet i nyere studier. Sykdomsmekanismen ved denne type syndromer i sentralnervesyste- 
met er derfor uklar, og det har fortsatt ikke vært mulig å lage gode dyremodeller for disse tilstandene. Det er sannsynlig at tidlig inflammasjon forutgår et senere stadium med utvikling av irreversibel nevronskade, og at dette er årsaken til at immunmodulerende behandling har liten effekt etter den primære fasen (3).

\section{Diagnostikk}

Paraneoplastiske nevrologiske sykdommer bør mistenkes hos pasienter med progredierende nevrologiske symptomer der annen årsak ikke kan påvises, spesielt ved funn fra flere deler av nervesystemet, eller ved samtidige allmennsymptomer, paraproteinemi eller patologiske lymfeknuter i mediastinum. Funn av inflammatoriske forandringer i spinalvæsken styrker mistanken.

MR av hjernen viser ofte normale eller uspesifikke funn ved paraneoplastiske nevrologiske sykdommer, særlig tidlig i sykdomsforløpet. Ved limbisk encefalitt kan man imidlertid se hyperintens oppladning $i$ en eller begge temporallapper også på et tidlig stadium (8). Ved tilstanden er spinalvæsken normal eller viser funn forenlig med inflammasjon (lymfocytær pleocytose, forhøyet spinalproteinnivå og oligoklonale bånd ved isoelektrisk fokusering). Nevrofysiologisk undersøkelse av perifere nerver og muskulatur er nyttig ved Lambert-Eatons myastenisk syndrom for påvisning av inkrement ved repetitiv nervestimulering, og ved paraneoplastisk nevropati påvises oftest en primær aksonal sensorisk eller sensoriskmotorisk nevropati.

Rundt halvparten av alle pasientene med paraneoplastiske nevrologiske syndromer har nevronantistoffer i serum og spinalvæske. Nevronantistoffene skal vanligvis ikke kunne påvises hos friske individer, og er så spesifikke at funn av et antistoff hos en pasient med nevrologiske symptomer definerer tilstanden som et slikt syndrom uavhengig av om det lykkes å påvise en svulst (4). Antistoffene er ofte assosiert med flere forskjellige svulster og flere ulike syndromer (tab 2). Antistoffpåvisning gjøres ved hjelp av immunhistokjemi, immunblotting og immunpresipiteringsteknikk (fig 2). I Norge utføres disse analysene ved Nevrologisk forskningslaboratorium ved Haukeland universitetssykehus, som mottar mer enn 1000 serumprøver $\mathrm{i}$ året for slik testing. Fordi samme antistoff kan være assosiert med flere syndromer og flere svulsttyper, er gode kliniske opplysninger en forutsetning for å kunne gi relevante tilbakemeldinger til rekvirent.

Hos mange pasienter med paraneoplastiske nevrologiske syndromer kan man imidlertid ikke påvise noen av de kjente nevronantistoffene, og fravær av antistoffer utelukker derfor ikke diagnosen.

Ved mistanke om tilstanden må det gjøres en omfattende malignitetsutredning, spesielt med henblikk på lunger, bryst og eggstok- ker/testikler. Ved paraneoplastiske nevrologiske syndromer er svulstene ofte små, og spesielt kan småcellet lungekreft billedmessig kun vises som beskjeden mediastinal lymfadenopati. Positronemisjonstomografi (PET) med fluoro-deoksyglukose som sporstoff kombinert med helkropps-CT, har vist seg å være mest sensitivt for å oppdage svulster hos disse pasientene. Denne modaliteten anbefales ved normale funn ved andre undersøkelser (28). Ved negativ kreftutredning og klinisk mistanke om paraneoplastiske nevrologiske syndromer anbefales gjentatte undersøkelser minimum hver sjette måned (29). Intervallet mellom paraneoplastiske nevrologiske syndromer og påvisbar kreft er vanligvis på rundt to til fire år, og oppfølgingen bør derfor minst være av en tilsvarende varighet og lengre ved påvisbare antistoffer.

Differensialdiagnosene til tilstanden er mange, avhengige av det enkelte syndromet. Det er sentralt å utelukke årsaker som vil medføre en annen terapeutisk tilnærming. For syndromene i det sentrale nervesystemet er det spesielt viktig å utelukke metabolske og infeksiøse årsaker og annen autoimmun sykdom, som for eksempel systemisk lupus erythematosus. Ved affeksjon av det perifere nervesystemet må også andre typer progredierende autoimmune nevropatier utelukkes.

\section{Behandling og prognose}

Behandling av paraneoplastiske nevrologiske syndromer kan deles i tre: kirurgisk og onkologisk behandling av den tilgrunnliggende svulsten, immunmodulerende terapi og symptomatisk behandling.

Klinisk erfaring tilsier at behandling av svulsten er det eneste som ser ut til å kunne stabilisere eller eventuelt delvis reversere de nevrologiske symptomene hos disse pasientene, men effekten avhenger av sykdomsvarighet og grad av irreversibel nevronskade (3). Kreftbehandling er sentralt for å begrense skaden i nervesystemet, og man må derfor ha en offensiv holdning til utredning og behandling av disse pasientene (7).

Immunmodulerende behandling som steroider, plasmaferese eller intravenøs immunglobulin har generelt sett bedre effekt ved affeksjon av det perifere enn av det sentrale nervesystemet, men vanligvis er bedringen midlertidig (29). Immunmodulerende terapi er derfor et supplement til kirurgisk og onkologisk behandling av svulsten, og bør brukes alene kun dersom slik behandling ikke er mulig. Pasienter med visse typer limbisk encefalitt har imidlertid ofte god nytte også av immunmodulerende behandling. I enkelte tilfeller med sannsynlig paraneoplastiske nevrologiske syndrom og nevronantistoffer har man gitt målrettet kjemoterapi uten verifisert kreftdiagnose (29), men det må understrekes at optimal utredning vil kunne påvise en svulst i mer enn $95 \%$ av tilfellene av paraneoplastiske nevrologiske syndromer.

Relevant symptomatisk behandling som antiepileptika, antidepressiver, analgetika og fysioterapi bør alltid igangsettes (29).

\section{Forskningsbetydning og fremtidige aspekter}

Paraneoplastiske nevrologiske sykdommer er sjeldne syndromer, men likevel av betydelig interesse både for klinikere og for forskere. Et viktig og ubesvart spørsmål er hvorfor disse sykdommene forekommer så sjelden når de

Tabell 2 Nevrologiske paraneoplastiske syndromer, de vanligste assosierte antistoffene og svulsttyper

Paraneoplastisk nevrologisk syndrom

Paraneoplastisk encefalomyelitt

Limbisk encefalitt

Paraneoplastisk cerebellar degenerasjon

Paraneoplastisk opsoklonusmyoklonus

Hjernestammeencefalitt

Ekstrapyramidale syndromer

Autonom dysfunksjon

Sensorisk-motorisk perifer nevropati

Subakutt sensorisk nevronopati

Paraneoplastisk autoimmunt stivhetssyndrom (stiff person syndromel

Synstap (cancer-assosiert retinopati)
Vanligste assosierte antistoffer

Hu, CRMP-5

$\mathrm{Hu}, \mathrm{Ma}, \mathrm{CRMP}-5$, VGKC

Yo, Hu, VGCC

Ri

Ri, Yo, $\mathrm{Hu}, \mathrm{Ma}$

CRMP-5

$\mathrm{Hu}$, VGCC

$\mathrm{Hu}, \mathrm{CRMP}-5$

$\mathrm{Hu}$

Amfifysin

Recoverin

Recoverin
Vanligste assosierte svulster

Småcellet lungekreft

Småcellet lungekreft, testikkelkreft, tymom

Ovarialkreft, brystkreft, småcellet lungekreft

Brystkreft, småcellet lungekreft

Brystkreft, gynekologiske svulster. småcellet lungekreft

Småcellet lungekreft

Småcellet lungekreft

Småcellet lungekreft

Småcellet lungekreft

Brystkreft

Småcellet lungekreft, malignt melanom 
onkonevrale antigenene uttrykkes så hyppig i svulster. Antistoffene forekommer også hos enkelte kreftpasienter uten nevrologiske symptomer. Dette tyder på at selv om mange kreftpasienter har en immunaktivering rettet mot onkonevrale antigener, må det være tilleggsfaktorer til stede for at de skal utvikle paraneoplastiske nevrologiske syndromer. Slike tilleggsfaktorer er imidlertid ukjent, men kan tenkes å være genetisk predisposisjon, utløsende infeksjon eller annen autoimmun sykdom. Assosiasjonen mellom teratom og limbisk encefalitt eller tymom og myasthenia gravis viser at svulsten heller ikke nødvendigvis trenger å være ondartet.

En annen sentral problemstilling er om immunresponsen faktisk holder kreftsvulsten i sjakk, slik at pasientene derved er et eksempel på vellykket naturlig tumorimmunitet. Nyere forskning har vist at det ikke er sammenheng mellom tilstedeværelse av nevronantistoffer og overlevelse av småcellet lungekreft (30). Paraneoplastiske nevrologiske syndromer betraktes som en gruppe modellsykdommer for tumorimmunitet og er derfor blitt kalt for «a window to cancer» (31). De er også gode eksempler på autoimmunitet og på hvordan systemsykdom kan slå over på det sårbare nervesystemet. Arbeidet med videre karakterisering av nevronantistoffer, onkonevrale antigener og kliniske undergrupper av paraneoplastiske nevrologiske syndromer vil forhåpentligvis ikke bare kunne bringe klarhet i viktige sykdomsmekanismer, men også kunne bidra til å identifisere pasientpopulasjoner som har særlig nytte av immunmodulerende behandling.

Oppgitte interessekonflikter: Ingen

Litteratur

1. Darnell RB, Posner JB. Paraneoplastic syndromes involving the nervous system. N Engl J Med 2003; 349: $1543-54$
2. Storstein A, Vedeler CA. Paraneoplastic neurologi cal syndromes and onconeural antibodies: clinical and immunological aspects. Adv Clin Chem 2007; 44: $143-85$.

3. Dalmau J, Rosenfeld MR. Paraneoplastic syndromes of the CNS. Lancet Neurol 2008; 7: 327-40.

4. Graus F, Delattre JY, Antoine JC et al. Recommended diagnostic criteria for paraneoplastic neurological syndromes. J Neurol Neurosurg Psychiatry 2004; 75: 1135-40.

5. Mygland A. Neurologiske paraneoplastiske syndromer og antineuron-antistoffer. Tidsskr Nor Lægeforen 1996; 116: 361-5.

6. Graus F, Keime-Guibert F, Reñe R et al. Anti-Huassociated paraneoplastic encephalomyelitis: analysis of 200 patients. Brain 2001; 124: 1138- 48.

7. Smitt PS, Grefkens J, de Leeuw B et al. Survival and outcome in 73 anti-Hu positive patients with paraneoplastic encephalomyelitis/sensory neuronopathy. J Neurol 2002; 249: 745-53.

8. Storstein A, Bru A, Vedeler CA. Limbisk encefalitt en diagnostisk utfordring. Tidsskr Nor Lægeforen 2007: 127: 3077-80.

9. Gultekin SH, Rosenfeld MR, Voltz R et al. Paraneoplastic limbic encephalitis: neurological symptoms, immunological findings and tumour association in 50 patients. Brain 2000; 123: 1481 -94

10. Dalmau J, Tüzün E, Wu HY et al. Paraneoplastic anti-N-methyl-D-aspartate receptor encephalitis associated with ovarian teratoma. Ann Neurol 2007; 61: 25-36

11. Sutton IJ, Barnett MH, Watson JD et al. Paraneoplastic brainstem encephalitis and anti-Ri antibodies. J Neurol 2002; 249: 1597-8.

12. Shams'ili S, Grefkens J, de Leeuw B et al. Paraneoplastic cerebellar degeneration associated with antineuronal antibodies: analysis of 50 patients. Brain 2003: 126: 1409-18

13. Bataller L, Graus F, Saiz A et al. Clinical outcome in adult onset idiopathic or paraneoplastic opsoclonus-myoclonus. Brain 2001; 124: 437-43.

14. Camdessanché JP. Antoine JC, Honnorat J et at. Paraneoplastic peripheral neuropathy associated with anti-Hu antibodies. A clinical and electrophysiological study of 20 patients. Brain 2002; 125 : $166-75$

15. Sørhaug S, Steinshamn SL, Waldum HL. Octreotide treatment for paraneoplastic intestinal pseudo-obstruction complicating SCLC. Lung Cancer 2005; 48: 137-40.

16. Lorusso L, Hart IK, Ferrari D et al. Autonomic paraneoplastic neurological syndromes. Autoimmun Rev 2007; 6: 162-8.

17. Antoine JC, Mosnier JF, Absi L et al. Carcinoma associated paraneoplastic peripheral neuropathies in patients with and without anti-onconeural antibodies. J Neurol Neurosurg Psychiatry 1999; 67: 7-14.
18. Storstein A, Vedeler C. Neuropathy and malignancy: a retrospective survey. J Neurol 2001; 248 $322-7$.

19. European Federation of Neurological Societies: Peripheral Nerve Society, Hadden RD, NobileOrazio E, Sommer C et al. European Federation of Neurological Societies/ Peripheral Nerve Society guideline on management of paraproteineamic demyelinating neuropathies. Eur J Neurol 2006; 13: $809-18$

20. Lang B, Pinto A, Giovannini F et al. Pathogenic autoantibodies in the Lambert-Eaton myasthenic syndrome. Ann N Y Acad Sci 2003; 998: 187-95.

21. Romi F, Gilhus NE, Aarli JA. Myasthenia gravis: clinical, immunological, and therapeutic advances. Acta Neurol Scand 2005; 111: 134-41.

22. Espay AJ, Chen R. Rigidity and spasms from autoimmune encephalomyelopathies: stiff-person syndrome Muscle Nerve 2006: 34: 677-90.

23. Holmøy T, Horn M, Vandvik B. En mann med stive bein og bisarr gange. Tidsskr Nor Lægeforen 2007 127: 1529-30.

24. Bataller L, Dalmau J. Neuro-ophthalmology and paraneoplastic syndromes. Curr Opin Neurol 2004 17: 3-8.

25. Muehlschlegel S, Okun MS, Foote KD et al. Paraneoplastic chorea with leukoencephalopathy presenting with obsessive-compulsive and behavioral disorder. Mov Disord 2005; 20: 1523-7.

26. Levine SM. Cancer and myositis: new insights into an old association. Curr Opin Rheumatol 2006; 18 $620-4$

27. Roberts WK, Darnell RB. Neuroimmunology of the paraneoplastic neurological degenerations. Curr Opin Immunol 2004; 16: 616-22.

28. Younes-Mhenni S, Janier MF, Cinotti L et al. FDGPET improves tumour detection in patients with paraneoplastic neurological syndromes. Brain 2004; 127: $2331-8$.

29. Vedeler CA, Antoine JC, Giometto B et al. Paraneoplastic Neurological Syndrome Euronetwork. Management of paraneoplastic neurological syndromes: report of an EFNS Task Force. Eur J Neurol 2006; 13: 682-90.

30. Monstad SE, Drivsholm L, Storstein A et al. Hu and voltage-gated calcium channel (VGCC) antibodies related to the prognosis of small-cell lung cancer. J Clin Oncol 2004; 22: 795-800.

31. Albert ML, Darnell RB. Paraneoplastic neurological degenerations: keys to tumour immunity. Nat Rev Cancer 2004; 4: 36-44.

Manuskriptet ble mottatt 3.6. 2008 og godkjent 19.12. 2008. Medisinsk redaktør Odd Terje Brustugun. 